\title{
Horticultural Performance of Greenhouse Cherry Tomatoes Irrigated Automatically Based on Soil Moisture Sensor Readings
}

\author{
Henrique Fonseca E. de Oliveira ${ }^{1}\left(\mathbb{D}\right.$, Hugo de Moura Campos ${ }^{1}$, Marcio Mesquita ${ }^{2}\left(\mathbb{D}\right.$, Roriz Luciano Machado ${ }^{1}$, \\ Luis Sérgio Rodrigues Vale ${ }^{1}$, Ana Paula Silva Siqueira ${ }^{3}$ and Rhuanito Soranz Ferrarezi ${ }^{4,5, *(\mathbb{B})}$ \\ 1 Cerrado Irrigation Graduate Program, Goiano Federal Institute, Ceres 76300-000, GO, Brazil; \\ henrique.fonseca@ifgoiano.edu.br (H.F.E.d.O.); hugo.campos@ifgoiano.edu.br (H.d.M.C.); \\ roriz.machado@ifgoiano.edu.br (R.L.M.); luis.sergio@ifgoiano.edu.br (L.S.R.V.) \\ 2 School of Agronomy, Federal University of Goiás, Goiânia 74690-900, GO, Brazil; marciomes@gmail.com \\ 3 Department of Food Science and Technology, Goiano Federal Institute, Urutaí 75790-000, GO, Brazil; \\ ana.siqueira@ifgoiano.edu.br \\ 4 Indian River Research and Education Center, Horticultural Sciences Department, University of Florida, \\ Fort Pierce, FL 34945, USA \\ 5 Department of Horticulture, University of Georgia, Athens, GA 30602, USA \\ * Correspondence: ferrarezi@uga.edu or rferrarezi@ufl.edu; Tel.: +1-706-542-0789
}

\section{check for}

updates

Citation: de Oliveira, H.F.E.; de Moura Campos, H.; Mesquita, M.; Machado, R.L.; Vale, L.S.R.; Siqueira, A.P.S.; Ferrarezi, R.S. Horticultural Performance of Greenhouse Cherry Tomatoes Irrigated Automatically Based on Soil Moisture Sensor Readings. Water 2021, 13, 2662. https://doi.org/10.3390/w13192662

Academic Editors: Rangjian Qiu and Zhenchang Wang

Received: 9 August 2021

Accepted: 22 September 2021

Published: 27 September 2021

Publisher's Note: MDPI stays neutral with regard to jurisdictional claims in published maps and institutional affiliations.

Copyright: (c) 2021 by the authors. Licensee MDPI, Basel, Switzerland. This article is an open access article distributed under the terms and conditions of the Creative Commons Attribution (CC BY) license (https:/ / creativecommons.org/licenses/by/ $4.0 /)$.

\begin{abstract}
Precision irrigation is essential to improve water use efficiency (WUE), defined as the amount of biomass produced per unit of water used by plants. Our objective is to evaluate the effect of different soil volumetric water content (VWC) in plant growth, fruit yield, quality, and WUE of cherry tomatoes grown in a greenhouse. We tested four VWC thresholds $(0.23,0.30,0.37$, and $0.44 \mathrm{~m}^{3} \mathrm{~m}^{-3}$ ) to trigger a drip irrigation system in two tomato cultivars ('Sweet Heaven' and 'Mascot F1'). The experiment was arranged in a split-plot design with four replications. We used capacitance sensors connected to an open-source, low-cost platform to monitor and control the irrigation in real-time based on demand. Plants were watered every time the soil VWC dropped below the set thresholds. The treatment with VWC $0.44 \mathrm{~m}^{3} \mathrm{~m}^{-3}$ resulted in the highest fruit yield, with $102.10 \%$ higher WUE when compared to the VWC $0.23 \mathrm{~m}^{3} \mathrm{~m}^{-3}$ in both cultivars. Fruit quality traits such as longitudinal and equatorial diameter increased asymptotically with soil water content. In contrast, treatments with deficit irrigation increased the fruit soluble solids by $15.73 \%$ in both cultivars. These results strongly suggest that accurate control of the soil VWC is essential to modulate the fruit yield and quality attributes in tomatoes produced in the greenhouse.
\end{abstract}

Keywords: Solanum lycopersicum var. cerasiforme; deficit irrigation; soluble solids content; water use efficiency

\section{Introduction}

The accelerated increase in the world's population and the unpredictable effects of climate change in agriculture require using natural resources like soil and water more efficiently to produce healthy and sustainable food [1]. Protected agriculture has been widely used in recent years to produce vegetables in order to improve agricultural systems productivity and quality and ensure consistency in production [2]. In addition to protecting the crops from pests and diseases and the adverse effects of extreme weather events, greenhouses guarantee year-round production and aid in higher water use efficiency (WUE) [3].

Water-saving technologies in protected environment production reduce water use and increase crop sustainability [4]. Supplemental irrigation is crucial in nutrient absorption and water uptake of greenhouse crops since they are not subjected to rainfall [5]. In a protected environment, excessive irrigation reduces water productivity and fruit quality [6]. 
In contrast, deficit irrigation has been proposed as a valuable strategy to save water and improve fruit yield and quality [7]. It is essential to determine water use accurately and in real-time for irrigation management to prevent overirrigation and water losses and guarantee water availability for other applications [8].

Innovative technologies such as soil moisture sensors can be helpful in water management [9]. However, the equipment used for precision irrigation tends to be expensive. It also requires extensive technical training for data collection and interpretation, making it difficult for untrained users to utilize for crop management [10]. Low-cost open-source platforms such as the do-it-yourself Internet-of-Things (IoT) prototyping embedded boards are viable options to facilitate customized microcontrollers in order to generate real-time data and assist users in making scientifically sound decisions $[9,10]$.

Cherry tomatoes (Solanum lycopersicum var. cerasiforme) are one of the most cultivated crops in protected environments due to the popularity of the sweet flavor, appearance, size, shape, and fruit quality [11]. Traditional tomato irrigation uses large amounts of water $[12,13]$. Therefore, accurate and efficient irrigation management is essential for the intensive production of greenhouse cherry tomatoes [14]. In most cases, increasing the amount of water applied increases fruit yield but decreases the fruit's soluble solids and lycopene content; conversely, deficit irrigation can limit fruit yield [5,15]. The period from fruit set to the end of fruit development is the most sensitive to water deficiency. During this time, adequate irrigation management can mitigate the damage caused by the water deficit [16]. Still, the irrigation timing and dose are essential-late and over-irrigation results in decreased fruit yield and quality [17].

Khapte et al. [7] indicated that deficit irrigation could alter the plant's physio-biochemical processes and consequently the WUE since this parameter depends on the intensity and duration of drought stress, growth stage, climate, and cultivar. Crop WUE can be increased if growers apply better agricultural practices or choose cultivars with higher potential yields [18].

Monitoring soil water status is critical to control the amount of stress plants are exposed to [19]. Several commercial sensors are available to measure soil water content accurately, but analyzing and processing the data is time-consuming, often resulting in water stress between the measurement and the irrigation triggering as watering is usually not activated automatically in real-time [20]. The increased demand for healthy foods provides an opportunity to use such technologies and obtain products with enhanced nutritional properties [21].

This study evaluated the effect of different volumetric water contents (VWC) applied using a low-cost open-source automated system controlled by soil moisture sensors on plant growth, fruit yield, and quality of cherry tomatoes grown in a greenhouse. We hypothesize that real-time irrigation based on VWC thresholds to trigger watering automatically on demand improves fruit yield, quality, and WUE of cherry tomatoes in a greenhouse.

\section{Materials and Methods}

\subsection{Experimental Site}

The experiment was performed at the Goiano Federal Institute in Ceres, GO, Brazil (latitude $15^{\circ} 21^{\prime} 01.5^{\prime \prime} \mathrm{S}$ longitude $49^{\circ} 35^{\prime} 55.2^{\prime \prime} \mathrm{W}$, and elevation $580 \mathrm{~m}$ ). The region climate was classified as Aw (tropical savannah climate with dry winter characteristics) according to the Köppen-Geiger classification [22]. The trial was conducted from August 2018 to February 2019 in an arch-type greenhouse (20-m long and 7-m wide) with a 120-micron plastic cover (Suncover AV Blue; Ginegar, Leme, SP, Brazil) and a 150-micron anti-aphid screen sides.

Temperature and relative humidity inside the greenhouse were recorded using a weather station (Vantage Pro 2; Davis; Hayward, CA, USA). The minimum and maximum air temperatures recorded were 19.2 and $40.4{ }^{\circ} \mathrm{C}$ (Figure $1 \mathrm{~A}$ ), and relative humidity ranged from $28 \%$ to $98 \%$, respectively (Figure 1B). Mean values for temperature and relative humidity throughout the study were $26.33{ }^{\circ} \mathrm{C}$ and $73.55 \%$, respectively. 

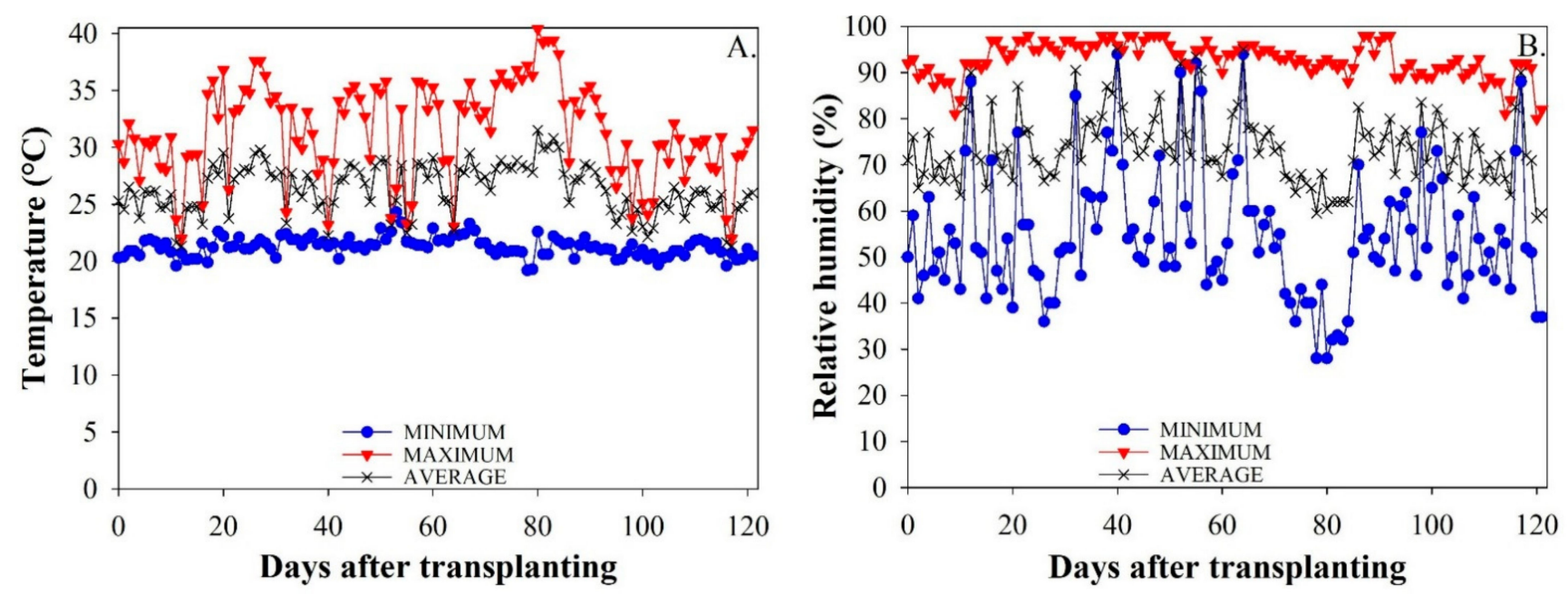

Figure 1. Temperature (A) and relative humidity (B) inside the greenhouse during the experimental period.

The soil used for the study is classified as a Red Latosol [23] composed of 59\% sand, 9\% silt, and $32 \%$ clay, with the following nutrient concentration: phosphorus $=1.8 \mathrm{mg} \mathrm{dm}^{-3}$, potassium $=34.5 \mathrm{mg} \mathrm{dm}^{-3}$, calcium $=1.5 \mathrm{cmol}_{\mathrm{C}} \mathrm{dm}^{-3}$, and magnesium $=0.7 \mathrm{cmol}_{\mathrm{C}} \mathrm{dm}^{-3}$, organic matter $=8.0 \mathrm{~g} \mathrm{dm}^{-3}, \mathrm{pH} \mathrm{CaCl}_{2}=5.9$, and base saturation $=60.71 \%$.

\subsection{Treatments}

We tested four different soil VWCs to trigger a drip irrigation system automatically when the substrate dropped below specific thresholds $\left(0.23,0.30,0.37\right.$, and $\left.0.44 \mathrm{~m}^{3} \mathrm{~m}^{-3}\right)$ based on [9,10], and two cherry tomato cultivars ('Mascot F1'; TopSeed Premium, Santo Antônio de Posse, SP, Brazil and 'Sweet Heaven'; Sakata Seeds Sudamérica, Bragança Paulista, SP, Brazil). The two cultivars were selected due to their regional popularity for greenhouse cultivation, high cash value, and expanding consumer market. However, little to no information is available regarding their performance under varying VWCs.

We used the gravimetric method to determine the soil water holding capacity and define the VWC treatments (data not shown). The saturation humidity was established at $0.44 \mathrm{~m}^{3} \mathrm{~m}^{-3}$ for the mixture containing 2:1 soil and sand, and we started decreasing the moisture content values in multiples of 0.07 until $0.23 \mathrm{~m}^{3} \mathrm{~m}^{-3}$, which imposes severe stress on the plants due to the proximity to the permanent wilting point.

The experiment was arranged in a split-plot design with four replications. The four VWC thresholds were allocated to the main plot, while two cherry tomato cultivars were in the sub-plot. Four plants were used per sub-plot, totaling 128 plants in the experiment.

\subsection{Plant Material}

Tomato seedlings were produced in polystyrene trays with 128 cells (Isoeste, Castanhal, PA, Brazil) by sowing one seed per cell in a soilless substrate composed of sphagnum peat, coconut fiber, rice husk, and vermiculite (Bioplant, Nova Ponte, MG, Brazil). Seedlings were transplanted 45 days after emergence (DAE) into 12-L flexible polyethylene pots $(23.5 \mathrm{~cm}$ height $\times 27 \mathrm{~cm}$ top width $\times 23.5 \mathrm{~cm}$ base width), containing a 2:1 soil and sand mixture.

\subsection{Irrigation System}

The experimental plots were watered using drip irrigation with $2 \mathrm{~L} \mathrm{~h}^{-1}$ self-compensating drippers (PCDS; Irritec, Indaiatuba, SP, Brazil). Irrigation was controlled by an automated system using a low-cost open-source prototyping board (Mega ADK; Arduino, Ivrea, Italy) connected to soil moisture sensors (10HS; Decagon Devices, Pullman, WA, USA), solenoid valves (HVF-100; Rain Bird, Azuza, CA, USA), and other devices. The soil moisture sensors were inserted vertically in the middle of the pot. Sensors were calibrated for the soil used in the study according to the methodology described by Cobos and Chambers [24]. 
The sensor readings were recorded every $30 \mathrm{~min}$, and the irrigation system was triggered automatically when the substrate VWC values dropped below the set thresholds $\left(0.23,0.30,0.37\right.$, and $\left.0.44 \mathrm{~m}^{3} \mathrm{~m}^{-3}\right)$. The system remained on for $60 \mathrm{~s}$, applying a volume of $33 \mathrm{~mL}$ per irrigation event, corresponding to a $0.60 \mathrm{~mm}$ water depth.

\subsection{Crop Management}

Plants were transplanted in double rows spaced $0.5 \mathrm{~m}$ in-row, $1.0 \mathrm{~m}$ between plants, and $1.5 \mathrm{~m}$ between double rows, equivalent to a population of 20,000 plants per hectare. The plants were supported using polythene strip tutors hanging from the ceiling (F-70 Tape; GP Sul, Porto Alegre, RS, Brazil). We performed weekly pinching of side shoots starting at 30 days after transplant (DAT). Weeds were removed manually during the experimental period. The pollination was performed naturally using air movement and induced by moving and repositioning the plants inside the greenhouse.

During the seedling transplant, soil moisture content was maintained at the soil field capacity $\left(0.37 \mathrm{~m}^{3} \mathrm{~m}^{-3}\right)$ following Agbna et al. [25] for plant acclimatization, and the treatment application began at 12 DAT.

\subsection{Measurements}

Plant height, stem diameter, root fresh, and dry weight were evaluated at the end of the experiment at 120 DAT following the methodology described by [26]. Roots were dried in a forced circulation oven at $65^{\circ} \mathrm{C}$ for $72 \mathrm{~h}$.

The longitudinal and equatorial diameters of the fruit were recorded after each harvest using a digital caliper (King Tools, Pompéia, SP, Brazil).

Fruit yield was determined by picking all mature fruit from all nine harvesting events. The harvest began on 13 November 2018 and ended on 25 January 2019, performed 7-10 days apart depending on the fruit maturation.

For fruit quality analysis, we sampled 10 random fruit per subplot after each harvest. The soluble solids content was determined using a digital refractometer (Brix/RI-Check; Reichert Technologies, Unterschleissheim, Munich, Germany). The content of phenolic compounds was determined using the method described by [27] for ether and aqueous ethanolic extracts. Measurement of antioxidant capacity was carried out based on methodologies described by [28,29] using the stable radical diphenyl picrylhydrazyl. The readings were taken using an ultra-violet spectrophotometer at $517 \mathrm{~nm}$.

The number of irrigation events was monitored and recorded throughout the experiment by the automated irrigation system. WUE was calculated using the following equation $[30,31]$.

$$
\text { Water use efficiency }\left(\mathrm{kg} \mathrm{m}^{-3}\right)=\frac{\text { Marketable fruit yield }\left(\mathrm{t} \mathrm{ha}^{-1}\right)}{\text { water depth }(\mathrm{mm})} \times 100
$$

\subsection{Statistical Analysis}

Data were tested for uniform or normal distribution and analyzed by analysis of variance (ANOVA) using SAS (version 9.4; SAS Institute, Cary, NC, USA). The cultivar was considered a qualitative factor and analyzed by Tukey multiple comparisons test, while VWC was considered a quantitative factor and analyzed using linear regression. Probability $(p)$ values $\leq 0.05$ were considered statistically significant.

\section{Results}

\subsection{Morphological Parameters}

Plant height differed significantly between the cultivars, with 'Mascot F1' $8.74 \%$ taller than 'Sweet Heaven' $(p<0.01)$. The VWC did not cause significant differences in the other morphological characteristics evaluated. The interaction between VWC and cultivars was significant for root dry weight $(p<0.05$, Table 1$)$. 
Table 1. Plant height, stem diameter, root fresh and dry weight of two cherry tomato cultivars in response to increasing volumetric water contents (VWC).

\begin{tabular}{|c|c|c|c|c|}
\hline & Plant Height & Stem Diameter & Root Fresh Weight & Root Dry Weight \\
\hline & $(\mathrm{cm})$ & $(\mathrm{mm})$ & $\left(\right.$ g plant $\left.^{-1}\right)$ & $\left(\right.$ g plant $\left.^{-1}\right)$ \\
\hline \multicolumn{5}{|l|}{ Cultivar } \\
\hline 'Sweet Heaven' & $227.50 \pm 27.70 b$ & $38.64 \pm 4.15$ & $9.37 \pm 4.31$ & $7.79 \pm 3.95$ \\
\hline 'Mascot F1' & $247.39 \pm 30.33 a$ & $39.36 \pm 5.88$ & $10.29 \pm 3.10$ & $9.37 \pm 4.06$ \\
\hline \multicolumn{5}{|l|}{ VWC } \\
\hline $0.23 \mathrm{~m}^{3} \mathrm{~m}^{-3}$ & $239.53 \pm 23.55$ & $35.30 \pm 6.04$ & $8.14 \pm 1.44$ & $6.70 \pm 1.59$ \\
\hline $0.30 \mathrm{~m}^{3} \mathrm{~m}^{-3}$ & $227.96 \pm 23.58$ & $38.79 \pm 2.46$ & $11.50 \pm 5.35$ & $10.00 \pm 5.31$ \\
\hline $0.37 \mathrm{~m}^{3} \mathrm{~m}^{-3}$ & $232.25 \pm 36.50$ & $38.91 \pm 3.57$ & $11.60 \pm 3.58$ & $11.08 \pm 4.50$ \\
\hline $0.44 \mathrm{~m}^{3} \mathrm{~m}^{-3}$ & $250.03 \pm 35.93$ & $42.99 \pm 4.74$ & $8.08 \pm 2.09$ & $6.54 \pm 1.56$ \\
\hline Source of variation & $p$-values & & & \\
\hline Cultivar & $0.0060 *$ & $0.5850 \mathrm{~ns}$ & $0.3152^{\mathrm{ns}}$ & $0.0651^{\mathrm{ns}}$ \\
\hline VWC & $0.7323^{\mathrm{ns}}$ & $0.7570^{\mathrm{ns}}$ & $0.3006^{\mathrm{ns}}$ & $0.1606^{\mathrm{ns}}$ \\
\hline Cultivar $\times$ VWC & $0.1949^{\mathrm{ns}}$ & $0.6054^{\mathrm{ns}}$ & $0.1979 \mathrm{~ns}$ & $0.0273^{* *}$ \\
\hline $\mathrm{R}^{2}$ & 0.999 & 0.9064 & 0.9919 & 0.9634 \\
\hline Coefficient of variation & $7.11 \%$ & $9.31 \%$ & $25.16 \%$ & $25.69 \%$ \\
\hline
\end{tabular}

The data presented is the mean \pm standard deviation $(n=4)$. Means followed by lowercase letters in the column differ statistically by Tukey multiple comparisons test. Where, ${ }^{*} p<0.01,{ }^{* *} p<0.05$, and ns: not significant. $\mathbf{R}^{2}$ : coefficient of determination. Coefficient of variation: $\sigma / \mu$, where $\sigma$ : standard deviation, and $\mu$ : average.

A regression model was fitted for the root dry weight values at different VWC for the cultivars 'Sweet Heaven' and 'Mascot F1'. The estimated optimum VWC were 0.319 and $0.330 \mathrm{~m}^{3} \mathrm{~m}^{-3}$, corresponding to a mean root dry weight of 9.79 and $12.32 \mathrm{~g}$ plant ${ }^{-1}$ for 'Sweet Heaven' and 'Mascot F1', respectively (Figure 2). The "Mascot F1" cultivar exhibited higher values for root dry weight than 'Sweet Heaven'.

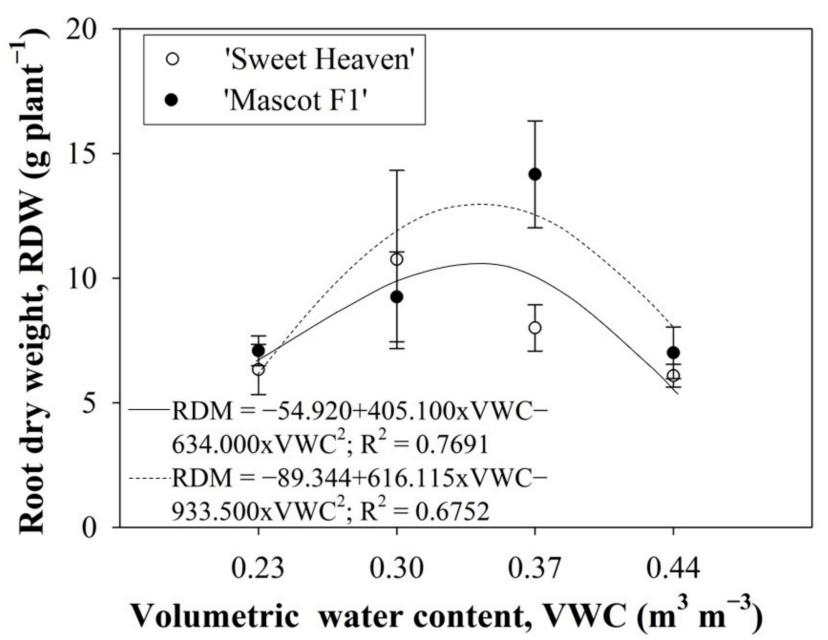

Figure 2. Root dry weight of two cherry tomato cultivars in response to increasing volumetric water contents. Each data point is the average of four replications $(n=4)$. The equations were fit using all replications.

\subsection{Fruit Quality}

The fruit quality parameters (longitudinal and equatorial diameter and soluble solids content) increased linearly with the increase in VWC without differences between cultivars except for the soluble solids content. The total phenolic content and antioxidant capacity did not differ between VWC and cultivars' tested levels (Table 2). 
Table 2. Longitudinal and equatorial diameter, total phenolic, antioxidant capacity, and soluble solids content of two cherry tomato cultivars in response to increasing volumetric water contents (VWC).

\begin{tabular}{|c|c|c|c|c|c|}
\hline & $\begin{array}{l}\text { Longitudinal } \\
\text { Diameter }\end{array}$ & $\begin{array}{l}\text { Equatorial } \\
\text { Diameter }\end{array}$ & Total Phenolic & $\begin{array}{l}\text { Antioxidant } \\
\text { Capacity }\end{array}$ & $\begin{array}{c}\text { Soluble Solids } \\
\text { Content }\end{array}$ \\
\hline & $(\mathrm{mm})$ & $(\mathrm{mm})$ & (EqAG mg/g) & $\left(\mathrm{IC}_{50}, \mu \mathrm{g} / \mathrm{mL}\right)$ & $(\%)$ \\
\hline \multicolumn{6}{|l|}{ Cultivar } \\
\hline 'Sweet Heaven' & $22.41 \pm 2.50$ & $18.15 \pm 2.24$ & $211.41 \pm 31.14$ & $2849.83 \pm 821.00$ & $9.03 \pm 0.44 b$ \\
\hline $\begin{array}{c}\text { 'Mascot F1' } \\
\text { VWC }\end{array}$ & $21.82 \pm 2.91$ & $17.83 \pm 2.77$ & $235.44 \pm 54.41$ & $2942.69 \pm 603.59$ & $9.33 \pm 0.74 \mathrm{a}$ \\
\hline $0.23 \mathrm{~m}^{3} \mathrm{~m}^{-3}$ & $18.11 \pm 1.65 c$ & $14.25 \pm 1.44 \mathrm{c}$ & $221.08 \pm 45.16$ & $3254.62 \pm 860.89$ & $9.93 \pm 0.49 a$ \\
\hline $0.30 \mathrm{~m}^{3} \mathrm{~m}^{-3}$ & $22.82 \pm 0.15 b$ & $18.48 \pm 0.32 b$ & $241.66 \pm 57.20$ & $2695.82 \pm 673.79$ & $9.20 \pm 0.32 b$ \\
\hline $0.37 \mathrm{~m}^{3} \mathrm{~m}^{-3}$ & $22.83 \pm 1.14 b$ & $18.70 \pm 0.75 b$ & $225.32 \pm 43.88$ & $2551.66 \pm 502.66$ & $9.03 \pm 0.37 b$ \\
\hline $0.44 \mathrm{~m}^{3} \mathrm{~m}^{-3}$ & $24.71 \pm 0.80 \mathrm{a}$ & $20.53 \pm 0.53 \mathrm{a}$ & $205.63 \pm 33.08$ & $3082.93 \pm 647.25$ & $8.58 \pm 0.35 c$ \\
\hline $\begin{array}{l}\text { Source of } \\
\text { variation }\end{array}$ & $p$-values & & & & \\
\hline Cultivar & $0.1082^{\mathrm{ns}}$ & $0.2798^{\mathrm{ns}}$ & $0.1713^{\mathrm{ns}}$ & $0.1868^{\mathrm{ns}}$ & $0.0403^{* *}$ \\
\hline VWC & $<0.0001$ * & $<0.0001$ * & $0.4757^{\mathrm{ns}}$ & $0.1243^{\mathrm{ns}}$ & $0.0001 *$ \\
\hline Cultivar $\times$ VWC & $0.2638^{\mathrm{ns}}$ & $0.1256^{\mathrm{ns}}$ & $0.3173^{\mathrm{ns}}$ & $0.6980^{\mathrm{ns}}$ & $0.1745^{\mathrm{ns}}$ \\
\hline $\mathrm{R}^{2}$ & 0.8251 & 0.8575 & 0.9144 & 0.9894 & 0.9434 \\
\hline $\begin{array}{l}\text { Coefficient of } \\
\text { variation }\end{array}$ & $4.35 \%$ & $4.40 \%$ & $20.91 \%$ & $22.81 \%$ & $4.04 \%$ \\
\hline
\end{tabular}

The data presented is the mean \pm standard deviation $(n=4)$. Means followed by lowercase letters in the column differ statistically by Tukey multiple comparisons test. Where, ${ }^{*} p<0.01,{ }^{* *} p<0.05$, and ns: not significant. $\mathrm{R}^{2}$ : coefficient of determination. Coefficient of variation: $\sigma / \mu$, where $\sigma$ : standard deviation, and $\mu$ : average.

The increase of $0.01 \mathrm{~m}^{3} \mathrm{~m}^{-3}$ in VWC resulted in an increase of 0.396 and $0.381 \mathrm{~mm}$ in the fruit's mean longitudinal and equatorial diameters. The longitudinal diameter was $22.41 \mathrm{~mm}$ for 'Sweet Heaven' and $21.82 \mathrm{~mm}$ for 'Mascot F1'; the equatorial diameter was 18.15 and $17.83 \mathrm{~mm}$ for the two cultivars, respectively (Figure 3).
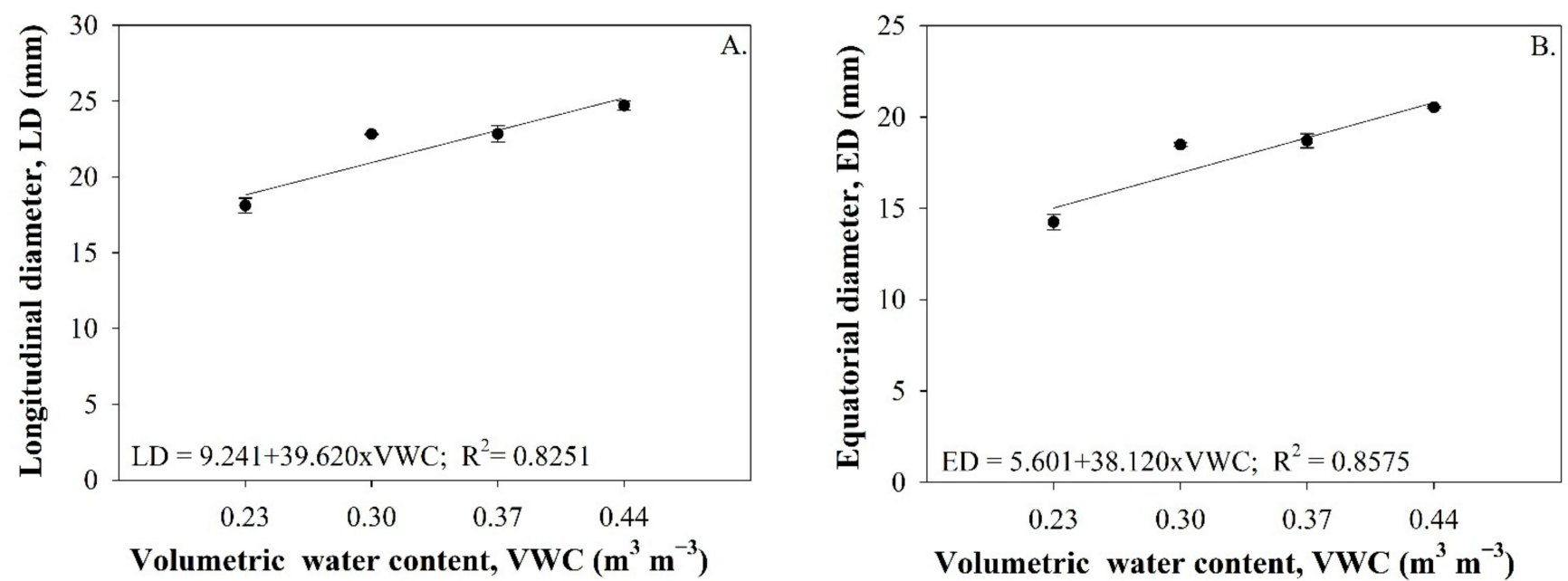

Figure 3. Longitudinal (A) and equatorial (B) diameter of two cherry tomato cultivars in response to increasing volumetric water contents. Each data point is the average of four replications $(n=4)$. The equations were fit using all replications.

There was a decrease in soluble solids content with increasing VWC (Figure 4). On average, 'Mascot F1' showed a soluble solids content (9.33\%) 3.32\% greater than 'Sweet Heaven' (9.03\%). According to the linear fit equation presented in Figure 4 , an increase of $0.01 \mathrm{~m}^{3} \mathrm{~m}^{-3}$ in VWC resulted in a reduction of $0.0838 \%$ in the soluble solids content. 


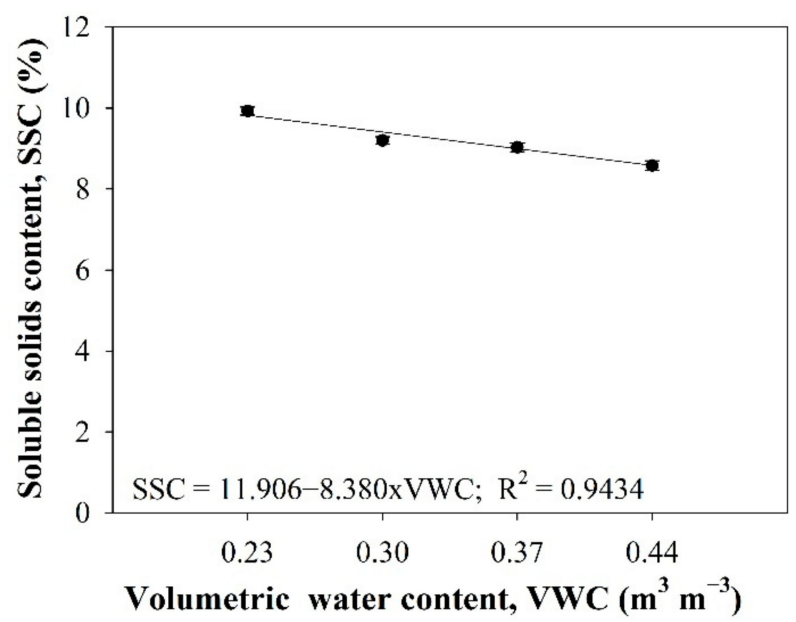

Figure 4. Soluble solids content of two cherry tomato cultivars in response to increasing volumetric water contents. Each data point is the average of four replications $(n=4)$. The equations were fit using all replications.

\subsection{Number of Irrigation Events, Fruit Yield, and Water Use Efficiency}

The treatments with VWC 0.23, 0.30, 0.37, and $0.40 \mathrm{~m}^{3} \mathrm{~m}^{-3}$ presented 427,573, 768, and 964 irrigation events, resulting in the water applied (depth) of 258.79, 347.27, 465.45, and $572.12 \mathrm{~mm}$, respectively. Treatment with VWC $0.44 \mathrm{~m}^{3} \mathrm{~m}^{-3}$ applied a total water depth of $572.12 \mathrm{~mm}, 121.07 \%$ greater than VWC $0.23 \mathrm{~m}^{3} \mathrm{~m}^{-3}$ at $258.79 \mathrm{~mm}$.

Fruit yield and WUE showed no statistical differences between the cultivars (Table 3); both parameters increased linearly with the increasing VWC (Figure 5).

Table 3. Fruit yield and water use efficiency of two cherry tomato cultivars in response to increasing volumetric water contents (VWC).

\begin{tabular}{|c|c|c|}
\hline & Fruit Yield & Water Use Efficiency \\
\hline & $\left(\mathrm{t} \mathrm{ha}^{-1}\right)$ & $\left(\mathrm{kg} \mathrm{m}^{-3}\right)$ \\
\hline \multicolumn{3}{|l|}{ Cultivar } \\
\hline 'Sweet Heaven' & $6.20 \pm 3.41$ & $1.43 \pm 0.49$ \\
\hline 'Mascot F1' & $6.60 \pm 3.35$ & $1.53 \pm 0.49$ \\
\hline \multicolumn{3}{|l|}{ VWC } \\
\hline $0.23 \mathrm{~m}^{3} \mathrm{~m}^{-3}$ & $2.46 \pm 0.62 c$ & $0.95 \pm 0.24 c$ \\
\hline $0.30 \mathrm{~m}^{3} \mathrm{~m}^{-3}$ & $5.99 \pm 1.41 \mathrm{~b}$ & $1.73 \pm 0.41 \mathrm{ab}$ \\
\hline $0.37 \mathrm{~m}^{3} \mathrm{~m}^{-3}$ & $6.15 \pm 1.42 b$ & $1.32 \pm 0.30 b c$ \\
\hline $0.44 \mathrm{~m}^{3} \mathrm{~m}^{-3}$ & $10.99 \pm 1.62 \mathrm{a}$ & $1.92 \pm 0.28 \mathrm{a}$ \\
\hline Source of variation & $p$-values & \\
\hline Cultivar & $0.5035^{\mathrm{ns}}$ & $0.4752^{\mathrm{ns}}$ \\
\hline VWC & $<0.0001 *$ & $0.0002 *$ \\
\hline Cultivar $\times$ VWC & $0.7954^{\mathrm{ns}}$ & $0.6798^{\mathrm{ns}}$ \\
\hline $\mathrm{R}^{2}$ & 0.9004 & 0.5555 \\
\hline Coefficient of variation & $25.71 \%$ & $26.06 \%$ \\
\hline
\end{tabular}

The data presented is the mean \pm standard deviation $(n=4)$. Means followed by lowercase letters in the column differ statistically by Tukey multiple comparisons test. Where, ${ }^{*} p<0.01$ and ns: not significant. $R^{2}$ : coefficient of determination. Coefficient of variation: $\sigma / \mu$, where $\sigma$ : standard deviation, and $\mu$ : average.

Fruit yield showed an increase of $0.368 \mathrm{t} \mathrm{ha}^{-1}$ for every $0.01 \mathrm{~m}^{3} \mathrm{~m}^{-3}$ increase in the VWC (Figure 5A). A higher yield of cherry tomato and WUE (Figure 5B) was observed for the VWC $0.44 \mathrm{~m}^{3} \mathrm{~m}^{-3}$, with $10.99 \mathrm{t} \mathrm{ha}^{-1}$ and $1.92 \mathrm{~kg} \mathrm{~m}^{-3}$, respectively. The treatments with VWC $0.23,0.30$, and $0.37 \mathrm{~m}^{3} \mathrm{~m}^{-3}$ achieved WUE of $0.95,1.73$, and $1.32 \mathrm{~kg} \mathrm{~m}^{-3}$. Increasing the VWC from 0.23 to $0.44 \mathrm{~m}^{3} \mathrm{~m}^{-3}$ resulted in a $346.75 \%$ increase in fruit yield. 
The plants exposed to deficit irrigation, i.e., plants grown in soils with VWC 0.23 and $0.30 \mathrm{~m}^{3} \mathrm{~m}^{-3}$, showed water deficit symptoms such as flower drop and wilting, reduced growth, and production of small-sized fruit.

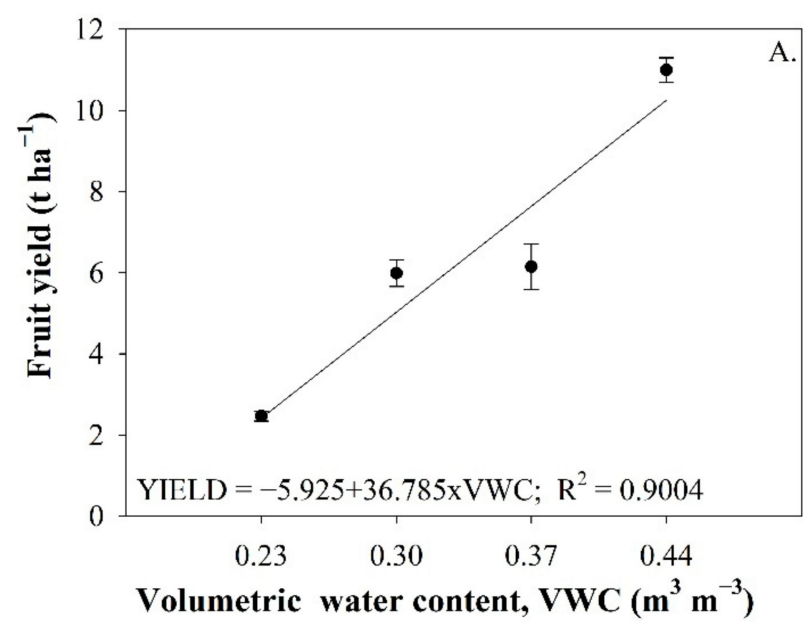

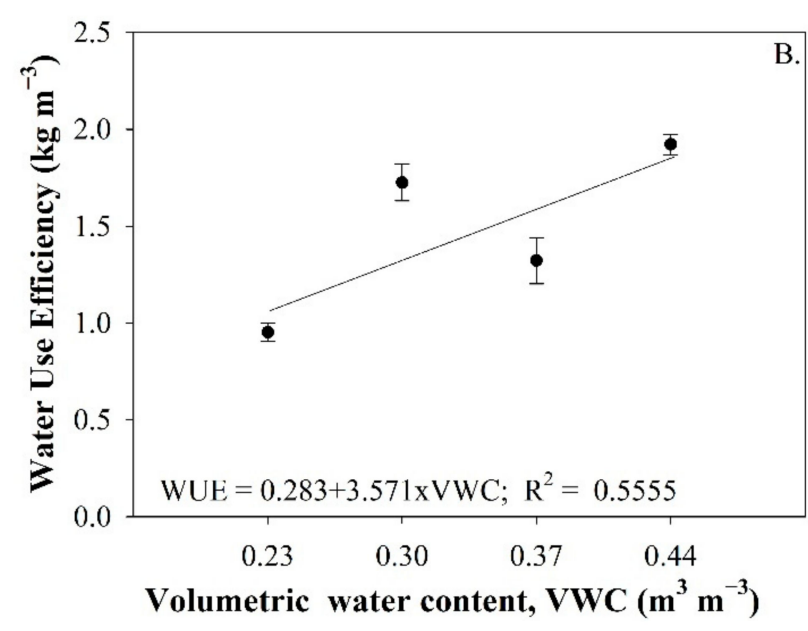

Volumetric water content, VWC $\left(\mathrm{m}^{3} \mathrm{~m}^{-3}\right)$

Figure 5. Fruit yield (A) and water use efficiency (WUE) (B) of two cherry tomato cultivars in response to increasing volumetric water contents. Each data point is the average of four replications $(n=4)$. The equations were fit using all replications.

\section{Discussion}

\subsection{Morphological Parameters}

In this study, the increase of VWC did not show significant differences in plant height, stem diameter, root fresh and root dry weight. The crop response to deficit irrigation depends on the period and extent of water deficit [32]. The results obtained in this study were similar to [33], which investigated the effect of irrigation levels on tomato plants grown in a greenhouse and reported no significant differences in plant height of plants subjected to different treatments.

The stem diameter increased linearly with the increase in VWC, probably due to the most frequent irrigation. Despite the potential for carbohydrate accumulation along the phloem (data not shown) [34], there was no significant difference between VWCs.

Tomatoes can develop a deep root system, increasing the plants' water availability and attenuating the harmful effects of water deficit [35]. In shallow soils or flexible pots, as in our experiment, the development in biomass of the root system was induced by a moderate water deficit, permitting greater secondary root branching and the main root deepening. However, the smaller volume of water available resulted in water stress and negatively impacted the fruit yield and WUE. For treatments without deficit irrigation, the root system showed more thin lateral roots in the upper layer. Earlier studies revealed that stomatal regulation is controlled through chemical signals from plant roots to the leaves, exposing plant roots to drying cycles [36]. Other mechanisms controlling stomatal aperture include hydraulic signals [37], water balance, leaf area and root system length reduction [38].

\subsection{Fruit Quality}

Several studies have demonstrated that deficit irrigation decreased the tomato fruit yield but improved the fruit quality $[35,39,40]$. Deficit irrigation has been used to reduce water use and increase the functional quality of tomatoes, including the effects on carotenoid and phenolic compounds [41].

The results showed an increase in soluble solids content inversely proportional to the irrigation amount in this study. For the longitudinal and equatorial diameter, the increase was directly proportional to the increase in the volume of water applied. The 
linear equation models obtained in this study are like those observed by other authors evaluating tomatoes' horticultural responses to different irrigation levels [42-46].

The accumulation of photo-assimilates in fruit under water stress may be caused by reduced fruit expansion and decreased water content, which causes osmotic stress [47,48]. A reduction in fruit size under deficit irrigation is mainly attributed to reducing water rather than reducing assimilates imported into the fruit [49]. The translocation of phloem sap to fruit is impeded under water deficit, increasing the sap solute concentration [31]. This could reduce water flow from the xylem to the fruit [50].

In this study, 'Mascot F1' showed a soluble solids content 3.32\% greater than 'Sweet Heaven', suggesting this parameter is crop-specific and that it can be influenced by horticultural traits [51]. The soluble solids content in all treatments in this study ranged from $8.58 \%$ to $9.93 \%$ and were higher than reported by [52] (7.6\% to $7.7 \%)$, [53] (7.1\% to $8.3 \%)$ and [35] (6.9\% to $7.3 \%)$.

The total phenolics did not change with irrigation and cultivar, similar to [54]. This response might be the case since phenolics are components of plant tissues. Their distribution is influenced by light and environmental conditions [53], which tend to be more homogeneous in a protected environment.

\subsection{Number of Irrigation Events, Fruit Yield, and Water Use Efficiency}

Several authors studying the fruit yield of tomato plants under different irrigation water depths have reported a linear and positive relationship between tomato yield and irrigation levels, similar to the present study [33,46].

It is well-known that high temperature and low irrigation frequency negatively affect the physiological processes in tomato plants, reducing the crop's horticultural performance [55]. The WUE was higher on VWC $0.44 \mathrm{~m}^{3} \mathrm{~m}^{-3}$ due to a high irrigation frequency, while in VWC $0.23 \mathrm{~m}^{3} \mathrm{~m}^{-3}$, the WUE was extremely low because of the reduced irrigation frequency.

The increase in air temperature inside greenhouses reduces the yield and quality of several crops. Thuoma et al. [56] explained that tomatoes could tolerate a moderate degree of stress, with about $20-30 \%$ depletion in available soil moisture in the plant root zone without significant fruit yield loss. Generally, a reduction of fruit weight occurs under more extended and intense periods of stress [35]. Our study recorded high temperatures inside the greenhouse during the experimental period since the greenhouse used had no temperature control system (Figure 1). A potential reduction in the number of fruit may be explained by the abortion of the flowers or the early drop of small fruit. Such responses can be alleviated by optimizing greenhouse water management [57], such as keeping a higher VWC to provide water as needed to the crop.

The WUE may vary greatly depending on the tomato cultivars, irrigation system, climatic conditions, and water quality [58]. The water deficit reduces water use, but it can negatively impact the fruit yield when applied continuously and not only in specific phenological phases [57].

The WUE decreased with increasing water shortage in the root zone, indicating that marketable fruit yield losses are proportionally greater than the reduction of water used by crops [35]. WUE responses to water shortage depend on the level of water stress experienced by the crop. Wang et al. [58], studying an extensive tomato germplasm collection cultivated under well-watered and water deficit conditions, concluded that the water deficit affected all the tomato cultivars tested, with a general decrease in fruit yield and increase in fruit quality.

Da Silva et al. [59], evaluating fruit yield and quality of greenhouse-grown tomato under limited water supply, noted that applying $1 / 3$ or $2 / 3$ of total irrigation amount at the fruit maturation and harvesting stage decreased the fruit yield by $23-41 \%$ but had the best fruit quality.

In the present study, a higher efficiency was founded for the treatment that applied a water depth of $572.12 \mathrm{~mm}$. Silva et al. [42] obtained greater efficiency in water use in 
treatments that applied water depth between 504 and $666 \mathrm{~mm}$, while [51] found greater water use efficiency in the treatment that applied $582.7 \mathrm{~mm}$. Other studies with tomato crops grown in different water depths in greenhouses [60,61] have shown that water deficit at different growth stages can directly affect the crop, significantly reducing plant growth and fruit yield.

In summary, a direct positive and linear correlation was found for fruit yield and WUE with an increase in soil VWC. Tomato fruit yield sharply decreased with the decrease in VWC to trigger irrigation (less water available), confirming that tomato crops require large amounts of water to sustain high yields.

\section{Conclusions}

This study tested the hypothesis that regulated soil water content improves the fruit yield, quality, and WUE of greenhouse tomatoes if the appropriate water content is maintained. The positive linear relationship between soil water content and cherry tomatoes' fruit quality provides the scientific basis for improving greenhouse crop production. The results showed that increasing the VWC could significantly boost fruit yield, longitudinal and equatorial diameter, and WUE of two tomato cultivars. The results confirmed that severe water stress has a negative effect on cherry tomato fruit yield and WUE. In contrast, deficit irrigation increased the fruit soluble solids by $15.73 \%$ in both cultivars. Analysis of all experimental data revealed that the VWC $0.44 \mathrm{~m}^{3} \mathrm{~m}^{-3}$ was optimal, resulting in the highest fruit yield, longitudinal and equatorial diameter, and $102.10 \%$ higher WUE when compared to the VWC $0.23 \mathrm{~m}^{3} \mathrm{~m}^{-3}$ in both cultivars. These results strongly suggest that accurate control of the soil VWC is essential to modulate the fruit yield and quality attributes in tomatoes produced in the greenhouse.

Author Contributions: Conceptualization, H.F.E.d.O. and R.S.F.; Data curation, H.d.M.C.; Formal analysis, H.d.M.C., M.M., R.L.M., L.S.R.V. and A.P.S.S.; Funding acquisition, H.F.E.d.O. and R.S.F.; Investigation, H.d.M.C. and R.S.F.; Methodology, H.d.M.C. and R.S.F.; Project administration, H.F.E.d.O.; Resources, H.F.E.d.O.; Software, H.d.M.C., M.M. and R.S.F.; Supervision, H.F.E.d.O. and R.S.F.; Validation, H.d.M.C. and H.F.E.d.O.; Visualization, L.S.R.V. and R.L.M.; Writing—original draft, H.F.E.d.O., H.d.M.C., M.M., R.L.M., L.S.R.V., A.P.S.S. and R.S.F.; Writing-review \& editing, H.F.E.d.O., H.d.M.C. and R.S.F. All authors have read and agreed to the published version of the manuscript.

Funding: Funding was provided by Goiano Federal Institute (Call for Proposals and Cooperative Projects of Applied Research No. 21/2015), U.S. Department of Agriculture (USDA) National Institute of Food and Agriculture (NIFA) Hatch/Multi-State W3128 "Scaling Microirrigation Technologies to Address the Global Water Challenge" (Accession no. 1015783), and USDA-NIFA Hatch/Multi-State W4128 "Microirrigation: A Sustainable Technology for Crop Intensification and Improved Crop Productivity" (Accession no. 1021596).

Institutional Review Board Statement: Not applicable.

Informed Consent Statement: Not applicable.

Data Availability Statement: The data sets generated and/or analyzed during the current study are available from the corresponding author on reasonable request.

Acknowledgments: The authors thank Cerrado Irrigation Graduate Program for technical support.

Conflicts of Interest: The authors declare no conflict of interest. The funders had no role in the study's design, in the collection, analyses, or interpretation of data, in the writing of the manuscript, or in the decision to publish the results.

\section{References}

1. Ćosić, M.; Djurović, N.; Stričević, R.; Savić, S.; Domazet, M. Effect of irrigation regime and application of kaolin on yield, quality, and water use efficiency of tomato. Sci. Hortic. 2015, 201, 271-278. [CrossRef]

2. $\quad$ Reis, L.S.; de Azevedo, C.A.V.; Albuquerque, A.W.; Junior, J.F.S. Îndice De Área Foliar E Produtividade Do Tomate Sob Condições De Ambiente Protegido. Rev. Bras. Eng. Agrícola Ambient. 2013, 17, 386-391. [CrossRef] 
3. Ya-dan, D.U.; Hong-xia, C.A.O.; Shi-quan, L.I.U.; Xiao-bo, G.U.; Yu-xin, C.A.O. Response of yield, quality, water, and nitrogen use efficiency of tomato to different levels of water and nitrogen under drip irrigation in Northwestern China. J. Integr. Agric. 2017, 16, 1153-1161. [CrossRef]

4. Ćosić, M.; Stričević, R.; Djurović, N.; Moravčević, D.; Pavlović, M.; Todorović, M. Predicting biomass and yield of sweet pepper grown with and without plastic film mulching under different water supply and weather conditions. Agric. Water Manag. 2017, 188, 91-100. [CrossRef]

5. Li, H.; Liu, H.; Gong, X.; Li, S.; Pang, J.; Chen, Z.; Sun, J. Optimizing irrigation and nitrogen management strategy to trade off yield, crop water productivity, nitrogen use efficiency and fruit quality of greenhouse-grown tomato. Agric. Water Manag. 2021, 245, 106570. [CrossRef]

6. Rostamza, M.; Chaichi, M.R.; Jahansouz, M.R.; Alimadadi, A. Forage quality, water use, and nitrogen utilization efficiencies of pearl millet (Pennisetum americanum L.) grown under different soil moisture and nitrogen levels. Agric. Water Manag. 2011, 98, 1607-1614. [CrossRef]

7. Khapte, P.S.; Kumar, P.; Burman, U.; Kumar, P. Deficit irrigation in tomato: Agronomical and physio-biochemical implications. Sci. Hortic. 2019, 248, 256-264. [CrossRef]

8. Zhou, W.; Xu, Z.; Ross, D.; Dignan, J.; Fan, Y.; Huang, Y.; Wang, G.; Bagtzoglou, A.; Lei, Y.; Li, B. Towards water-saving irrigation methodology: Field test of soil moisture profiling using flat thin mm-sized soil moisture sensors (SMSs). Sens. Actuators B Chem. 2019, 298, 126857. [CrossRef]

9. Ferrarezi, R.S.; van Iersel, M.W. Monitoring and controlling ebb-and-flow subirrigation with soil moisture sensors. HortScience 2015, 50, 447-453. [CrossRef]

10. Ferrarezi, R.S.; Dove, S.K.; van Iersel, M.W. An automated system for monitoring soil moisture and controlling irrigation using low-cost open-source microcontrollers. HortTechnology 2015, 25, 110-118. [CrossRef]

11. Junqueira, A.H.; da Silva Peetz, M. Sweet Grape: Um Modelo de Inovação na Gestão da Cadeia de Produção e Distribuição de Hortaliças Diferenciadas no Brasil; ESPM Central de Cases: São Paulo, Brasil, 2011; pp. 1-16.

12. Giuliani, M.M.; Nardella, E.; Gatta, G.; De Caro, A.; Quitadamo, M. Processing Tomato Cultivated under Water Deficit Conditions: The Effect of Azoxystrobin. Acta Hortic. 2011, 914, 287-294. [CrossRef]

13. Lu, J.; Shao, G.; Gao, Y.; Zhang, K.; Wei, Q.; Cheng, J. Effects of water deficit combined with soil texture, soil bulk density and tomato variety on tomato fruit quality: A meta-analysis. Agric. Water Manag. 2021, 243, 106427. [CrossRef]

14. He, Z.; Li, M.; Cai, Z.; Zhao, R.; Hong, T.; Yang, Z.; Zhang, Z. Optimal irrigation and fertilizer amounts based on a multi-level fuzzy comprehensive evaluation of yield, growth, and fruit quality on a cherry tomato. Agric. Water Manag. 2021, $243,106360$. [CrossRef]

15. Wang, X.; Xing, Y. Evaluation of the effect of irrigation and fertilization by drip fertigation on tomato yield and water use efficiency in the greenhouse. Int. J. Agron. 2016, 2016, 3961903. [CrossRef]

16. Nemeskéri, E.; Neményi, A.; Bocs, A.; Pék, Z.; Helyes, L. Physiological factors and their relationship with the productivity of processing tomato under different water supplies. Water 2019, 11, 586. [CrossRef]

17. Lahoz, I.; Pérez-de-Castro, A.; Valcárcel, M.; Macua, J.I.; Beltrán, J.; Roselló, S.; Cebolla-Cornejo, J. Effect of water deficit on the agronomical performance and quality of processing tomato. Sci. Hortic. 2016, 200, 55-65. [CrossRef]

18. El-Marsafawy, S.M.; Swelam, A.; Ghanem, A. Evolution of crop water productivity in the Nile Delta over three decades (1985-2015). Water 2018, 10, 1168. [CrossRef]

19. Cui, J.; Shao, G.; Lu, J.; Keabetswe, L.; Hoogenboom, G. Yield, quality and drought sensitivity of tomato to water deficit during different growth stages. Sci. Agric. 2020, 77, e20180390. [CrossRef]

20. Takács, S.; Pék, Z.; Csányi, D.; Daood, H.; Szuvandzsiev, P.; Palotás, G.; Helyes, L.D. Influence of water stress levels on the yield and lycopene content of tomato. Water 2020, 12, 2165. [CrossRef]

21. González-Casado, S.; Martín-Belloso, O.; Elez-Martínez, P.; Soliva-Fortuny, R. Induced accumulation of individual carotenoids and quality changes in tomato fruits treated with pulsed electric fields and stored at different post-treatments temperatures. Postharvest Biol. Technol. 2018, 146, 117-123. [CrossRef]

22. Kottek, M.; Grieser, J.; Beck, C.; Rudolf, B.; Rubel, F. World map of the Köppen-Geiger climate classification updated. Meteorol. Z. 2006, 15, 259-263. [CrossRef]

23. Santos, H.G.; Jacomine, P.K.T.; dos Anjos, L.H.C.; de Oliveira, V.A.; Lumbreras, J.F.; Coelho, M.R.; de Almeida, J.A.; de Araujo Filho, J.C.; de Oliveira, J.B.; Cunha, T.J.F. Sistema Brasileiro de Classificação de Solos, 5th ed.; Embrapa Solos: Rio de Janeiro, Brazil, 2018; 355p.

24. Cobos, C.; Chambers, D.R. Calibrating ECH2O Soil Moisture Sensors. 2018. Available online: https://www.metergroup.com/ environment/articles/how-calibrate-soil-moisture-sensors / (accessed on 7 September 2018).

25. Agbna, G.H.D.; Dongli, S.; Zhipeng, L.; Elshaikh, N.A.; Guangcheng, S.; Timm, L.C. Effects of deficit irrigation and biochar addition on the growth, yield, and quality of tomato. Sci. Hortic. 2017, 222, 90-101. [CrossRef]

26. Borges, B.M.M.N.; Lucas, F.T.; de M. Modesto, R.; Prado, V.C.; Silva, B.B.; da Braos, E.S. Métodos de determinação da matéria seca e dos teores de macronutrientes em folhas de alface. Rev. Trópica Ciências Agrárias Biológicas 2011, 5, 12-16.

27. Zieliński, H.; Kozłowska, H. Antioxidant activity and total phenolics in selected cereal grains and their different morphological fractions. J. Agric. Food Chem. 2000, 48, 2008-2016. [CrossRef]

28. Blois, M.S. Antioxidant Determinations by the use of a stable free radical. Nat. Microbiol. 1958, 182, 800-801. [CrossRef] 
29. Brand-Williams, W.; Cuvelier, M.E.; Berset, C. Use of a free radical method to evaluate antioxidant activity. LWT—Food Sci. Technol. 1995, 28, 25-30. [CrossRef]

30. Yang, H.; Du, T.; Qiu, R.; Chen, J.; Wang, F.; Li, Y.; Wang, C.; Gao, L.; Kang, S. Improved water use efficiency and fruit quality of greenhouse crops under regulated deficit irrigation in northwest China. Agric. Water Manag. 2017, 179, 193-204. [CrossRef]

31. Liu, H.; Li, H.; Ning, H.; Zhang, X.; Li, S.; Pang, J.; Wang, G.; Sun, J. Optimizing irrigation frequency and amount to balance yield, fruit quality, and water use efficiency of greenhouse tomato. Agric. Water Manag. 2019, 226, 105787. [CrossRef]

32. Lu, J.; Shao, G.; Cui, J.; Wang, X.; Keabetswe, L. Yield, fruit quality, and water use efficiency of tomato for processing under regulated deficit irrigation: A meta-analysis. Agric. Water Manag. 2019, 222, 301-312. [CrossRef]

33. De Lima, T.P.; Gomes Filho, R.R.; Cadore, R.; Freitas, D.S.; De Carvalho, C.M.; De Aguiar Netto, A.O. Lâminas de irrigação e formas de adubação na produção de tomate de mesa. Agropecuária Técnica 2017, 38, 18. [CrossRef]

34. Brito, M.E.B.; dos Anjos Soares, L.A.; de Lima, G.S.; da Silva Sá, F.V.; de Araújo, T.T.; Silva, E.C.B. Crescimento e formação de fitomassa do tomateiro sob estresse hídrico nas fases fenológicas. Irriga 2015, 20, 139-153. [CrossRef]

35. Cantore, V.; Lechkar, O.; Karabulut, E.; Sellami, M.H.; Albrizio, R.; Boari, F.; Stellacci, A.M.; Todorovic, M. Combined effect of deficit irrigation and strobilurin application on yield, fruit quality, and water use efficiency of 'Cherry' tomato (Solanum lycopersicum L.). Agric. Water Manag. 2016, 167, 53-61. [CrossRef]

36. Kirda, C.; Cetin, M.; Dasgan, Y.; Topcu, S.; Kaman, H.; Ekici, B.; Derici, M.R.; Ozguven, A.I. Yield response of greenhouse-grown tomato to partial root drying and conventional deficit irrigation. Agric. Water Manag. 2004, 69, 191-201. [CrossRef]

37. Augé, R.M.; Moore, J.L. Stomatal response to nonhydraulic root-to-shoot communication of partial soil drying in relation to foliar dehydration tolerance. Environ. Exp. Bot. 2002, 47, 217-229. [CrossRef]

38. Fara, S.J.; Delazari, F.T.; Gomes, R.S.; Araújo, W.L.; da Silva, D.J.H. Stomata opening and productiveness response of fresh market tomato under different irrigation intervals. Sci. Hortic. 2019, 255, 86-95. [CrossRef]

39. Patanè, C.; Saita, A. Biomass, fruit yield, water productivity and quality response of processing tomato to plant density and deficit irrigation under a semi-arid Mediterranean climate. Crop Pasture Sci. 2015, 66, 224-234. [CrossRef]

40. Martí, R.; Valcárcel, M.; Brondo, M.L.; Lahoz, I.; Campillo, C.; Roselló, S.; Cornejo, J.C. Influence of controlled deficit irrigation on tomato functional value. Food Chem. 2018, 252, 250-257. [CrossRef] [PubMed]

41. Malheiros, S.M.M.; e Silva, Ê.F.d.F.; de Medeiros, P.R.F.; Pedrosa, E.M.R.; Rolim, M.M.; Santos, A.N. Cultivo hidropônico de tomate cereja utilizando-se efluente tratado de uma indústria de sorvete. Rev. Bras. Eng. Agrícola Ambient. 2012, 16, 1085-1092. [CrossRef]

42. Silva, C.J.; Pontes, N.C.; Golynski, A.; Braga, M.B.; Quezado-Duval, A.M.; Silva, N.E. Performance of processing tomatoes under different supply levels of crop evapotranspiration. Hortic. Bras. 2018, 36, 299-305. [CrossRef]

43. Santiago, E.J.P.; de Oliveira, G.M.; Leitão, M.d.M.V.B.R.; de Carvalho Rocha, R.; Pereira, A.V.A. Yield characteristics of cherry tomato cultivated with and without shading screen at different irrigation levels. Pesqui. Agropecu. Trop. $2018,48,374-381$. [CrossRef]

44. Santiago, E.J.P.; de Oliveira, G.M.; Leitão, M.d.M.V.B.R.; de Carvalho Rocha, R.; Pereira, A.V.A. Qualidade do tomate cereja cultivado sob lâminas de irrigação em ambiente protegido e campo aberto. Agrometeoros 2018, 26, 213-221. [CrossRef]

45. Wang, C.; Gu, F.; Chen, J.; Yang, H.; Jiang, J.; Du, T.; Zhang, J. Assessing the response of yield and comprehensive fruit quality of tomato grown in greenhouse to deficit irrigation and nitrogen application strategies. Agric. Water Manag. 2015, 161, 9-19. [CrossRef]

46. Kumar, P.S.; Singh, Y.; Nangare, D.D.; Bhagat, K.; Kumar, M.; Taware, P.B.; Kumari, A.; Minhas, P.S. Influence of growth stage specific water stress on the yield, physicochemical quality and functional characteristics of tomato grown in shallow basaltic soils. Sci. Hortic. 2015, 197, 261-271. [CrossRef]

47. Nangare, D.D.; Singh, Y.; Kumar, P.S.; Minhas, P.S. Growth, fruit yield, and quality of tomato (Lycopersicon esculentum Mill.) as affected by deficit irrigation regulated on phenological basis. Agric. Water Manag. 2016, 171, 73-79. [CrossRef]

48. Zegbe, J.A.; Behboudian, M.H.; Clothier, B.E. Response of tomato to partial rootzone drying and deficit irrigation. Rev. Fitotec. Mex. 2007, 30, 125-131.

49. Guichard, S.; Bertin, N.; Leonardi, C.; Gary, C. Tomato fruit quality in relation to water and carbon fluxes. Agronomie 2001, 23, 407-418. [CrossRef]

50. Coyago-Cruz, E.; Meléndez-Martinez, A.J.; Moriana, A.; Girón, I.F.; Martín-Palomo, M.J.; Galindo, A.; Pérez-Lopez, D.; Torrecillas, A.; Beltrán-Snchiguano, E.; Corell, M. Yield response to regulated deficit irrigation of greenhouse cherry tomatoes. Agric. Water Manag. 2019, 213, 212-221. [CrossRef]

51. Figàs, M.R.; Prohens, J.; Raigón, M.D.; Fernández-de-Córdova, P.; Fita, A.; Soler, S. Characterization of a collection of local varieties of tomato (Solanum lycopersicum L.) using conventional descriptors and the high-throughput phenomics tool Tomato Analyzer. Genet. Resour. Crop Evol. 2015, 62, 189-204. [CrossRef]

52. Coyago-Cruz, E.; Corell, M.; Stinco, C.M.; Hernanz, D.; Moriana, A.; Meléndez-Martínez, A.J. Effect of regulated deficit irrigation on quality parameters, carotenoids, and phenolics of diverse tomato varieties (Solanum lycopersicum L.). Food Res. Int. 2017, 96, 72-83. [CrossRef] [PubMed]

53. Coyago-Cruz, E.; Corell, M.; Moriana, A.; Hernanz, D.; Benítez-Gonzales, A.S.M.; Stinco, C.M.; Meléndez-Martínez, A.J. Antioxidants (carotenoids and phenolics) profile of cherry tomatoes as influenced by deficit irrigation, ripening and cluster. Food Chem. 2018, 240, 870-884. [CrossRef] [PubMed] 
54. Hasanuzzaman, M.; Nahar, K.; Alam, M.M.; Roychowdhury, R.; Fujita, M. Physiological, biochemical, and molecular mechanisms of heat stress tolerance in plants. Int. J. Mol. Sci. 2013, 14, 9643-9684. [CrossRef] [PubMed]

55. Rodriguez-Ortega, W.M.; Martinez, V.; Rivero, R.M.; Camara-Zapata, J.M.; Mestre, T.; Garcia-Sanchez, F. Use of a smart irrigation system to study the effects of irrigation management on the agronomic and physiological responses of tomato plants grown under different temperatures regimes. Agric. Water Manag. 2017, 183, 158-168. [CrossRef]

56. Valcárcel, M.; Lahoz, I.; Campillo, C.; Martí, R.; Leiva-Brondo, M.; Roselló, S.; Cebolla-Cornejo, J. Controlled deficit irrigation as a water-saving strategy for processing tomato. Sci. Hortic. 2020, 261, 108972. [CrossRef]

57. Ihuoma, S.O.; Madramootoo, C.A. Sensitivity of spectral vegetation indices for monitoring water stress in tomato plants. Comput. Electron. Agric. 2019, 163, 104860. [CrossRef]

58. Wang, F.; Kang, S.; Du, T.; Li, F.; Qiu, R. Determination of a comprehensive quality index for tomato and its response to different irrigation treatments. Agric. Water Manag. 2011, 98, 1228-1238. [CrossRef]

59. Da Silva, J.M.; Ferreira, R.S.; de Melo, A.S.; Suassuna, J.F.; Dutra, A.F.; Gomes, J.P. Cultivo do tomateiro em ambiente protegido sob diferentes taxas de reposição da evapotranspiração. Rev. Bras. Eng. Agrícola Ambient. 2012, 17, 40-46. [CrossRef]

60. Li, Y.; Sun, Y.; Liao, S.; Zou, G.; Zhao, T.; Chen, Y.; Yang, J.; Zhang, L. Effects of two slow-release nitrogen fertilizers and irrigation on yield, quality, and water-fertilizer productivity of greenhouse tomato. Agric. Water Manag. 2017, 186, 139-146. [CrossRef]

61. Du, Y.D.; Niu, W.Q.; Gu, X.B.; Zhang, Q.; Cui, B.J. Water- and nitrogen-saving potentials in tomato production: A meta-analysis. Agric. Water Manag. 2018, 210, 296-303. [CrossRef] 